\title{
8
}
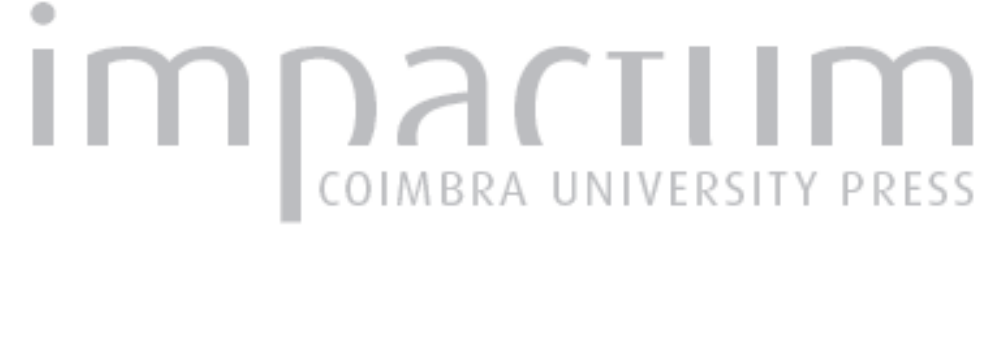

\section{Vox Mediarama}

Rodrigues, Américo; Monteiro, Alfredo Costa; Bennett, John; Italiano, Autor(es): $\quad$ Juan Angel; Bravo, Luis; Davis, AG; Seiça, Alvaro; Ruehlen, Ryan Deumier, Sandrine; Lamy, Philippe; LaLiberty, Ryan; Miloykovitch, Vladimir Vladda; Pinheiro, Sara; Prescott-Steed, David

Publicado por: Centro de Literatura Portuguesa; Imprensa da Universidade de Coimbra

URL persistente:

URI:http://hdl.handle.net/10316.2/43620

DOI:

DOI:https://doi.org/10.14195/2182-8830_5-1_6

Accessed : $\quad$ 26-Apr-2023 15:16:34

A navegação consulta e descarregamento dos títulos inseridos nas Bibliotecas Digitais UC Digitalis, UC Pombalina e UC Impactum, pressupõem a aceitação plena e sem reservas dos Termos e Condições de Uso destas Bibliotecas Digitais, disponíveis em https://digitalis.uc.pt/pt-pt/termos.

Conforme exposto nos referidos Termos e Condições de Uso, o descarregamento de títulos de acesso restrito requer uma licença válida de autorização devendo o utilizador aceder ao(s) documento(s) a partir de um endereço de IP da instituição detentora da supramencionada licença.

Ao utilizador é apenas permitido o descarregamento para uso pessoal, pelo que o emprego do(s) título(s) descarregado(s) para outro fim, designadamente comercial, carece de autorização do respetivo autor ou editor da obra.

Na medida em que todas as obras da UC Digitalis se encontram protegidas pelo Código do Direito de Autor e Direitos Conexos e demais legislação aplicável, toda a cópia, parcial ou total, deste documento, nos casos em que é legalmente admitida, deverá conter ou fazer-se acompanhar por este aviso. 


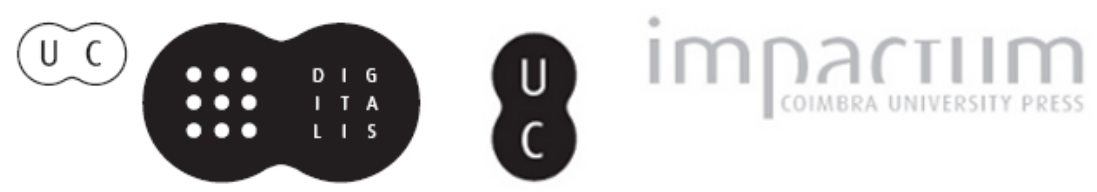

impactum.uc.pt digitalis.uc.pt 


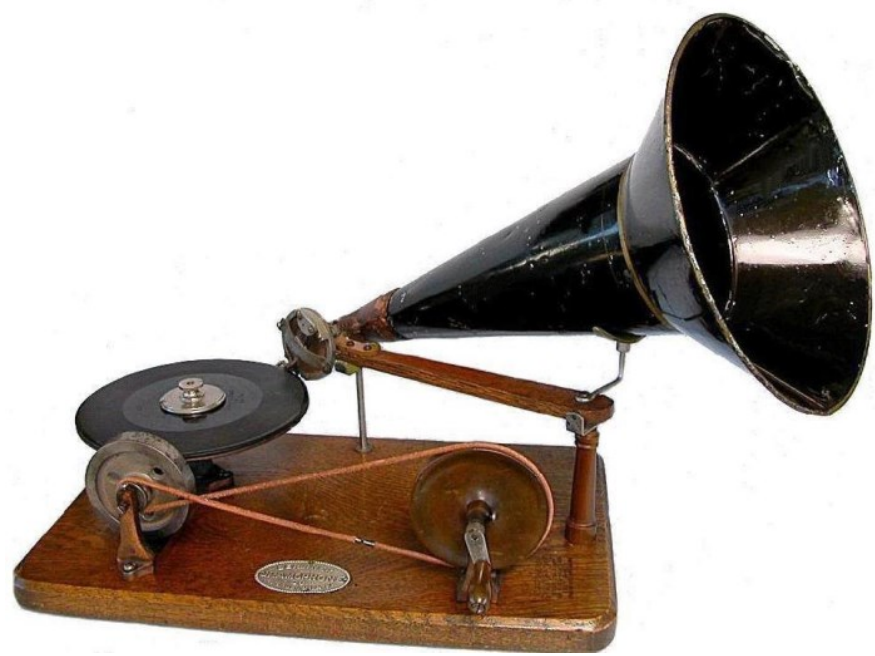

ช2

త్ర

త్ర్త్ర

(⿻)

घ)

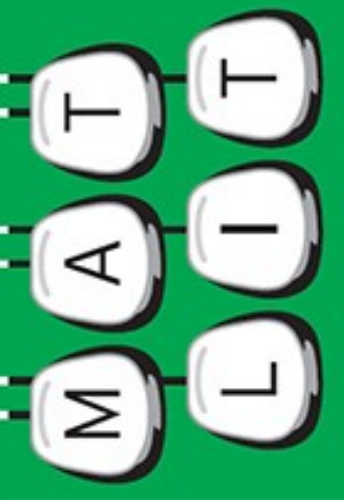

Vol. 5.1 (2017)

ISSN 2182-8830

'Vox Media: O Som na Literatura'

Osvaldo Manuel Silvestre e

Felipe Cussen (orgs.) 


\section{adverCidade (voz e papel) AMÉRICO RODRIGUES}

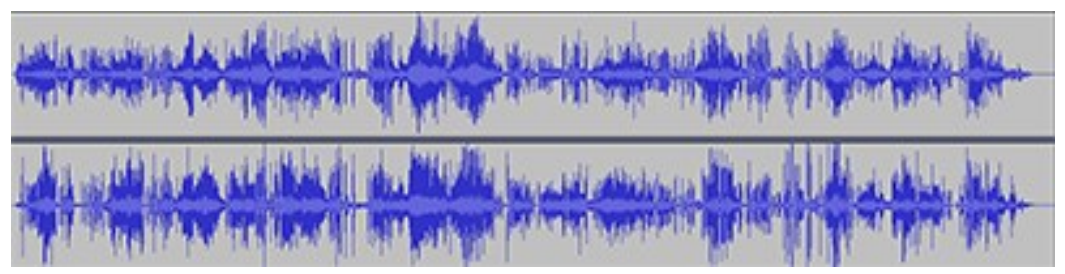

http://impactum-journals.uc.pt/matlit/article/view/5043/4150

\section{Resumo}

adverCidade (voz e papel) (dezembro de 2016) é a peça criada por Américo Rodrigues para integrar este número da revista Materialidades da Literatura. Construída a partir de um complexo jogo linguístico, e das possibilidades combinatórias que este potencia, adverCidade é afinal uma reflexão sobre o lugar do poeta na praça de jorna: são as multifacetas de uma cidade (Guarda?) onde o poeta (Américo?) é o seu mais feroz e fricativo adversário, adverso a contra-verso, dado como nado morto — mas vivo! ainda que amordaçado, adVergastado, como se ouve ecoando nos gemidos e rugidos de um Américo capaz de engolir cidades e adverCidades. Em primeiro plano, o poeta pReverso diverte-se na decomposição da palavra, um trava-língua travado à partida advvvvffff..... enunciando o verso do verso jamais converso na voz adversa.

\section{Abstract}

adverCity (December 2016) is a piece created by Américo Rodrigues to be part of this issue of Materialities of Literature. Based on the combinatorics of a complex linguistic game, adverCity is, in the end, a reflection about the place of the poet as a worker for hire: such are the multifaces of a city (Guarda?) where the poet (Américo?) is its most ferocious and fricative opponent, adverse to counter-verse, announced as still-born but still alive! - even if gagged, wHipped, as one hears in the echoing groans and roars of a cities- and adverCities-swallowing Américo. In the foreground, the pReverse poet amuses himself with the decomposition of the word, a twisted tonguetwister from the start advvvffffff ....... enunciating the never controverted verse in his adverse voice.

(C) 2017 Américo Rodrigues.

Licensed under the Creative Commons Attribution-NoncommercialNo Derivative Works 4.0 International (CC BY-NC-ND 4.0). 


\title{
INTIMA MENTE
}

\author{
Alfredo Costa Monteiro
}

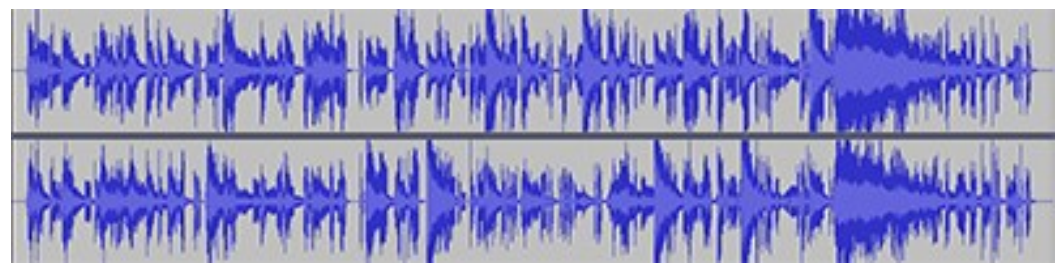

http://impactum-journals.uc.pt/matlit/article/view/5037/4152

\section{Resumo}

A estrutura de íntima mente obedece a uma lógica não só fonética mas também semântica. As palavras são utilizadas pelas suas caraterísticas e similitudes sonoras e pelas suas possibilidades polissémicas. Assim, o texto vai evoluindo não só por um método de construção que tem que ver com o poético, mas sobretudo por uma organização sonora feita de jogos de palavras, de assonâncias, consonâncias ou aliterações. É o som a apoderar-se do sentido. Este método que busca a palavra dentro da própria palavra leva também a vestígios de narração que, neste caso, falam do que está oculto por detrás da linguagem, do que diz o que não sempre se ouve, do que às vezes emerge do que pensamos ser. Uma voz solta lá por dentro da própria voz. Todos os sons utilizados são o resultado de manipulações sonoras de três parâmetros: distorção, tom e reverberação, a partir da voz principal.

\section{Abstract}

The structure of íntima mente follows not only a phonetic but also a semantic rationale. Words are used for their sound similarities and for their polysemic possibilities. Thus, the text evolves not only by a method of construction that has to do with the poetic, but above all by a sound organization made up of word games, assonances, consonances or alliterations. It is sound seizing sense. This method, which searches for the word within the word itself, also leads to traces of narration which, in this case, speak of what is hidden behind language, of what is not always heard, what sometimes emerges from what we think we are. A loose voice inside its own voice. All the sounds used in this work are the result of sound manipulations of three parameters: distortion, tone and reverberation of the main voice.

(C) 2017 Alfredo Costa Monteiro. Licensed under the Creative Commons Attribution-NoncommercialNo Derivative Works 4.0 International (CC BY-NC-ND 4.0). 


\title{
the fisted neck
}

\section{JOHN BENNETT}

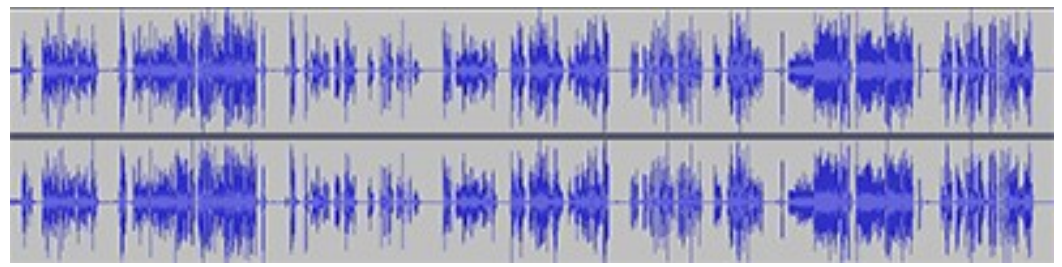

http://impactum-journals.uc.pt/matlit/article/view/5036/4212

\begin{abstract}
half a door and clown right clasp, your knob ck ck ck 1 icks un $g$ ate sleep inside the hose yr Faucet vapor eats my end raw nor meat

\section{Resumo}

half a door and clown right clasp, your knob ck ck ck 1 icks un $g$ ate sleep inside the hose yr Faucet vapor eats my end raw nor meat
\end{abstract}

Licensed under the Creative Commons Attribution-NoncommercialNo Derivative Works 4.0 International (CC BY-NC-ND 4.0). 


\title{
Galaxia vocálica JUAN ANGEL ITALIANO
}

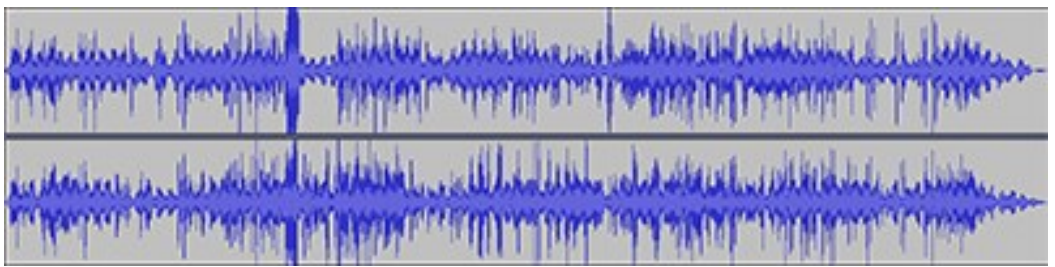

http://impactum-journals.uc.pt/matlit/article/view/4787/4226

\begin{abstract}
Resumen
Galaxia vocálica (00:05:27) es una posible interpretación sonora del texto de Pedro Xisto "VOGALAXIA" (Ed. Invenção/San Paulo - 1966) en el que las vocales (elemento de trabajo) están relacionadas entre sí. La oralización de la obra, sigue las sugerencias del autor, las vocales suenan abiertas o cerradas, nasales, acentuadas, susurradas, aceleradas, cantadas, solas o en coros, en una permutación constante. La lectura de las secuencias fueron verticales, horizontales, transversales o circulares, buscando la construcción de una representación sonora de un universo vocálico, de una galaxia de vocales. Incluye el sonido modificado de una proeminencia solar captada por el A.I.A. multiband instrument del Solar Dynamics Observatory (NASA). Se buscó a la hora de la edición explotar las diferentes direcciones del paneo, para generar la idea de multiplicidad de fuentes de origen del sonido.
\end{abstract}

\begin{abstract}
Vocalic Galaxy (00:05:27) is a possible sound interpretation of the text by Pedro Xisto "VOGALAXIA" (Ed. Invenção/São Paulo - 1966) in which the vowels (working elements) are related to each other. The oralization of the work follows the suggestions of the author: the vowels sound open or closed, nasal, accented, whispered, accelerated, sung, alone or in chorus, in a constant permutation. The readings of the sequences were vertical, horizontal, transverse or circular, looking for the construction of a sound representation of a vowel universe, a galaxy of vowels. It includes the modified sound of a solar prominence captured by the A.I.A. multiband instrument from the Solar Dynamics Observatory (NASA). At the moment of editing, different directions of the soundscape were explored in order to generate the idea of multiplicity of sources of sound origin.
\end{abstract}

C) 2017 Juan Angel Italiano.

Licensed under the Creative Commons Attribution-NoncommercialNo Derivative Works 4.0 International (CC BY-NC-ND 4.0). 


\section{0 minutos de ronquidos y lluvia (poema material del poeta soñante) LUIS BRAVO}

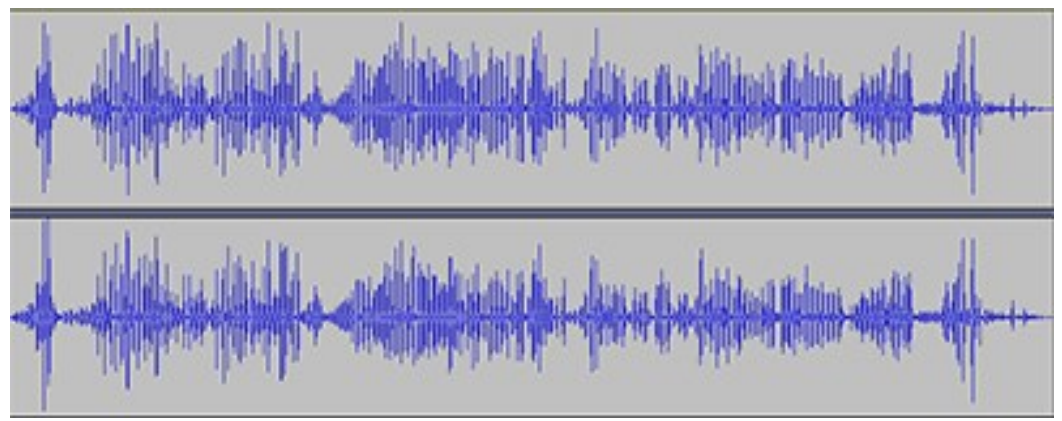

http://impactum-journals.uc.pt/matlit/article/view/5047/4171

\section{Resumen}

\section{A. Concepto:}

1. La grabación fue registrada al azar una noche en un hotel durante un viaje, en 2014. El grabador quedó prendido, el poeta durmiente.

2. La grabación se edita y se convierte en pieza poética desde una elaboración conceptual surgida a partir de la convocatoria de Vox Media.

3. El ronquido, que no es voz, constituye una sonoridad incontrolada. La performance agrega la materialidad de toda la representación.

4. La pieza desde lo material es el audiograma del sueño. Desde lo onírico es sonoridad del inconsciente trabajando.

5. Síntesis: la performance incluye las variaciones del ronquido, los sonidos de la lluvia, el soñar del durmiente, el azar del registro grabado, el trabajo inconsciente del poeta. 6. La duración (10 minutos) integra la materialidad del poema.

B. Instalación: pautas para la emisión. La manera simple para la escucha de la pieza es con auriculares en un equipo estéreo. Se sugiere agregar una escucha deslindada, si el equipo cuenta con alternancia de canales. a) Una primera escucha del canal izquierdo; b) una segunda del canal derecho; c) una tercera de ambos canales en estéreo. Canal izquierdo: paisaje sonoro (ronquido y lluvia) en tiempo lineal. Canal derecho: ciertas alteraciones del orden de las secuencias producen otras combinaciones sonoras. El estéreo, ambos canales a la vez, alterna los ronquidos a modo de contrapunto. Postproducción de audio realizada en el "labOratorio" Maldonado, Uruguay.

\section{Abstract}

A. Concept:

1. Sounds were recorded at random one night in a hotel during a trip, in 2014. The recorder was left on, while the poet was sleeping. 
2. The recording was edited and becomes a poetic piece following its conceptual elaboration arising from the Vox Media call.

3. Snoring, which is not a voice, constitutes an uncontrolled sonority. The performance brings together the materiality of the whole representation.

4. Considered from this material basis the piece is the audiogram of the dream. Considered from the oniric perspective it is the sonority of the unconscious working. 5. Synthesis: the performance includes the variations of the snoring, the sounds of the rain, the dream of the sleeper, the chance recording of the sounds, the unconscious work of the poet.

6. The duration (10 minutes) is part of the materiality of the poem. B. Installation: guidelines for the transmission. The simple way to listen to this piece is with headphones on a stereo. It is suggested that listeners experiment with alternating channels, if the equipment allows for alternating channels. a) For a first listening, use the left channel; b) for a second listening, use the right channel; c) for the third, use both channels in stereo. Left channel: sound landscape (snoring and rain) in linear time. Right channel: certain alterations of the ordering of the sequences produce other sound combinations. The stereo, both channels at the same time, alternates the snoring as in counterpoint. Audio post-production made in the "labOratorio" Maldonado, Uruguay.

(C) 2017 Luis Bravo.

Licensed under the Creative Commons Attribution-NoncommercialNo Derivative Works 4.0 International (CC BY-NC-ND 4.0). 


\section{Shatoe}

AG DAVIS

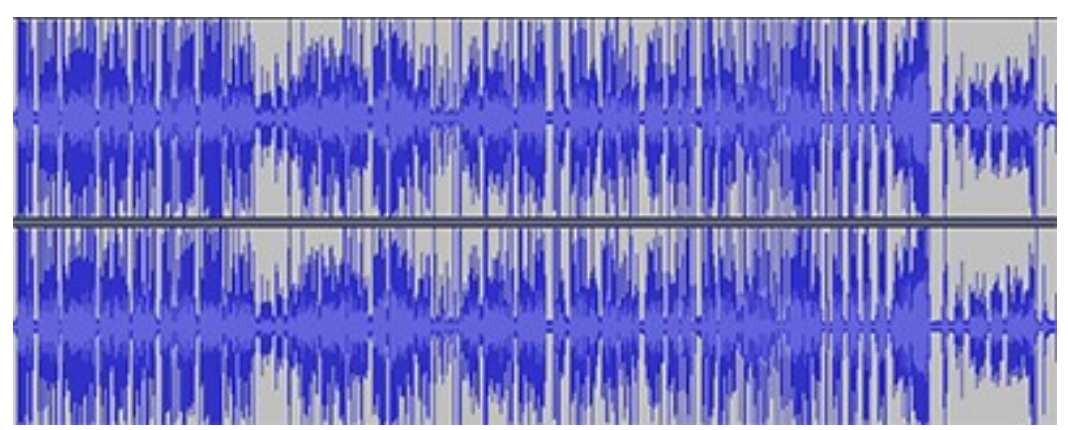

http://impactum-journals.uc.pt/matlit/article/view/5041/4216

\section{Abstract}

"Shatoe" has as its primary concept the release of primal language from the basic drives of the human condition, and language's corresponding role in the expression of those drives therein. The words are "primal" in the sense that their usage is not semantically driven through learned reflection, but whose uses are "chosen" spontaneously through glossolalia to purely reflect a given psychological condition. The piece was not written out, and was performed with my eyes closed as i deeply assessed my mental situation at the given moment (which happened to be one of intense freefloating desire for I know not what). Ultimately, "Shatoe" is an expression of that desire in its purest spoken-word form possible.

\section{Resumo}

"Shatoe" tem como conceito primário a libertação da linguagem primordial dos impulsos básicos da condição humana, e do papel respetivo da linguagem na expressão desses impulsos. As palavras são "primordiais" no sentido em que a sua utilização não é conduzida semanticamente pela reflexão aprendida, mas pelos usos que são "escolhidos" espontaneamente através da glossolália, de modo a refletir uma dada condição psicológica. A peça não foi anotada e foi realizada com os olhos fechados enquanto acedia profundamente ao meu estado mental (que calhou a ser o de um de intenso desejo flutuante por qualquer coisa que desconheço). No final, "Shatoe" é uma expressão desse desejo na sua forma de palavra-dita o mais pura possível.

(C) 2017 AG Davis.

Licensed under the Creative Commons Attribution-NoncommercialNo Derivative Works 4.0 International (CC BY-NC-ND 4.0). 


\section{As valas abertas Álvaro SEIÇA}

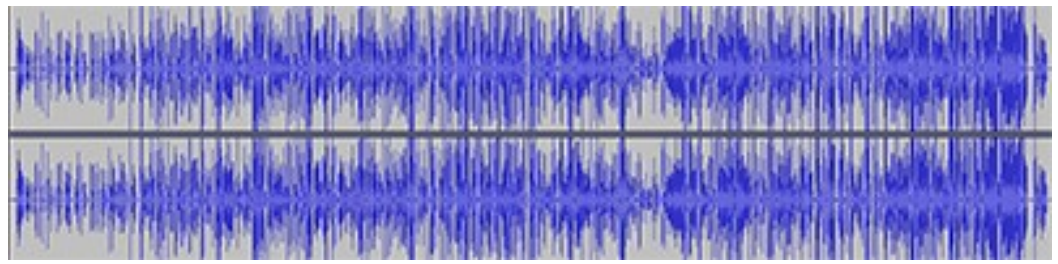

http://impactum-journals.uc.pt/matlit/article/view/5042/4172

\section{Resumo}

as valas abertas ++ des fossés ouverts ++ open ditches é um poema composto por 40 linhas com o máximo de 80 caracteres por linha. O poema explora regras de composição e temas presentes no conto "A Biblioteca de Babel" (1941) de Jorge Luis Borges. O poema foi criado como resposta a um desafio, Langlibabex (2014), uma peça de poesia simultânea multilíngue desenvolvida em colaboração com Claire Donato e Luc Dall'Armellina.

$\mathrm{Em}$ as valas abertas ++ des fossés ouverts ++ open ditches coexistem níveis e funções plurais de modos de leitura, visto que o navegador e a voz humana reproduzem a leitura do código fonte com uma saída visual e emissão sonora distintas. A voz humana apresenta uma leitura literal do código HTML, enquanto que a leitura do navegador omite certas passagens que estão inseridas dentro de marcadores HTML inventados e não-estandardizados, que se relacionam com o corpo humano dentro do marcador $<$ body $>$. Os vários corpos realçam fricções e tensões entre agentes humanos e não-humanos na sua relação com a linguagem e o código: as linguagens ditas "naturais" e as linguagens de programação.

$\mathrm{Na}$ altura em que o poema foi escrito, corpos vivos cavavam inúmeras valas abertas na Ucrânia, que estavam já destinadas a futuros corpos mortos, mas desconhecidos. O poema entrelaça este facto com os factos ficcionais de Borges. Foi composto e gravado em Paris, em Novembro de 2014, em português, inglês, francês e HTML. O poema e o ficheiro mp3 podem ser descarregados em:

http:/ / alvaroseica.net/works/as-valas-abertas.html.

\section{Abstract}

as valas abertas ++ des fossés ouverts ++ open ditches is a poem constrained by 40 lines with a maximum of 80 characters per line. The poem draws from constraints and themes addressed by Jorge Luis Borges's short story "The Library of Babel” (1941). It has been created for Langlibabex (2014), a multilingual and simultaneous poetry piece developed in collaboration with Claire Donato and Luc Dall'Armellina.

In as valas abertas ++ des fossés ouverts ++ open ditches different levels and functions of reading co-exist, given that when the browser and human voice reproduce the reading of its source code the visual and sound outputs differ. The human voice 
provides a literal reading of the HTML code, whereas the browser's output omits certain sections that are contained within invented-non-standardized-HTML tags relating to the human body, inside the tag $\langle$ body $>$. The various bodies highlight frictions and tensions among human and non-human agents in relation to language and code: the so-called "natural" languages and programming languages.

At the time of the writing process, alive bodies were digging uncountable open ditches in Ukraine for soon-to-be, yet unknown, dead bodies. The poem weaves this fact with Borges's fictional facts. It was composed and recorded in Paris in November 2014, in Portuguese, English, French, and HTML. The poem and the source mp3 file can be downloaded at http://alvaroseica.net/works/as-valas-abertas.html.

(C) 2017 Álvaro Seiça.

Licensed under the Creative Commons Attribution-NoncommercialNo Derivative Works 4.0 International (CC BY-NC-ND 4.0). 


\section{Narrative Currents \\ RYAN WADE RUEHLEN AND MARK AMERIKA}

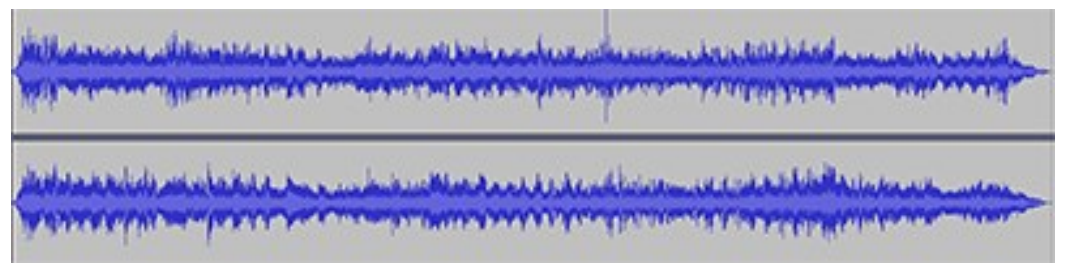

http://impactum-journals.uc.pt/matlit/article/view/5050/4220

\section{Abstract}

This work remixes the natural sounds of Boulder Creek (where the dialogue takes place) with some of the random urban noise and background ambience of the nearby thoroughfare. Ruptures in language indicate an intentional manipulation of the source material and useful postproduction techniques such as feedback and repetition highlight the affective qualities of the act of listening and deciphering. Meanwhile the dialogue itself creates its own metanarrative investigating what kinds of immersive listening experiences can be created using audio source material as the primary component of storytelling and how sound narrative can be a form of electronic literature.

\section{Resumo}

Este trabalho remistura os sons naturais de Boulder Creek (onde o diálogo tem lugar) com algum do ruído urbano e som ambiente aleatórios da via vizinha. As ruturas na linguagem indicam uma manipulação intencional de alguns dos materiais originais e técnicas apropriadas de pós-produção, tais como o feedback ou a repetição, sublinham as qualidades afectivas do acto de escuta e de descodificação. Simultaneamente, o próprio diálogo cria a sua metanarrativa e investiga que tipos de experiências de escuta imersivas podem ser criadas usando o material de fonte de áudio como o principal componente da narrativa e de como a narrativa sonora pode ser uma forma de literatura eletrónica.

(C) 2017 Ryan Wade Ruehlen and Mark Amerika. Licensed under the Creative Commons Attribution-NoncommercialNo Derivative Works 4.0 International (CC BY-NC-ND 4.0). 


\section{MATLIT-v. 5 \\ JOHN F. BARBER}

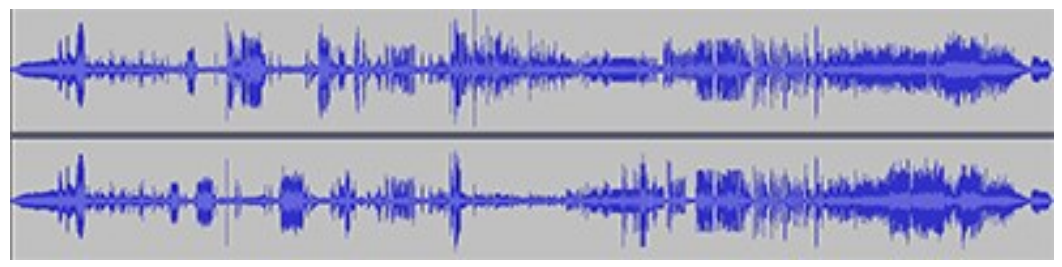

http://impactum-journals.uc.pt/matlit/article/view/5046/4208

\section{Abstract}

To demonstrate through listening the aesthetic concept and practices described in my text essay, “Vox Media: Sound, 'under language,' and 'narrative archaeology' in/as Literature," also submitted for this special issue. Recombining/ reconceptualizing sound artifacts promotes broader opportunities for conceptualizing and creating literary artifacts characterized by audibility of text, sound as text and meaning, and heightened awareness of the author's/speaker's voice(s) in the text. Tensions produced by these combinations may help foreground conceptualizations and practices regarding sound-based texts. Specifically, these combinations of technologies and performances may help challenge the past invisibility of voice in literature and promote future digital media and textuality theory and practices more rewarding than simulacra, description, or transcription. Vox Media. Sound in/as literature. From something comes something more: electronic literature as sound-based narrative composed from sound poetry, text-sound composition, and/or sound art.

\section{Resumo}

Demonstrar através da escuta o conceito e prática estéticas descritas no meu ensaio "Vox Media: Sound, 'under language', and 'narrative archaeology' in/as Literature", também submetido a este número especial da revista. A recombinação/ reconceptualização de artefactos sonoros promove oportunidades mais amplas para a conceptualização e criação de artefactos literários caracterizados pela audibilidade do texto, do som como texto e como significado, e de uma consciência aumentada da voz do autor/falante no texto. As tensões produzidas por estas combinações podem ajudar a colocar em primeiro plano conceitos e práticas relativos aos textos baseados no som. Mais especificamente, estas combinações entre tecnologias e performances podem ajudar a contestar a invisibilidade da voz na literatura do passado e a promover os média digitais futuros e a teoria da textualidade bem como práticas mais estimulantes do que o simulacro, a descrição, ou a transcrição. Vox Media. Som como/na literatura. De algo surge algo mais: a literatura electrónica como narrativa baseada no som composta a partir da poesia sonora, da composição texto-som, e/ou da arte sonora. 


\title{
Like a Letter, You JESSICA BARNESS AND VinCE GILES
}

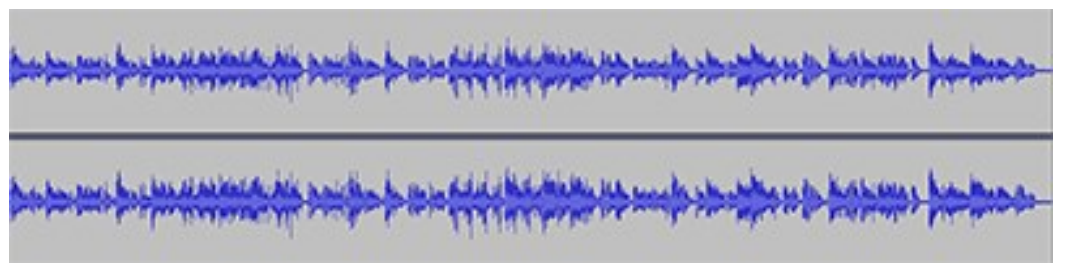

http://impactum-journals.uc.pt/matlit/article/view/5045/4210

\begin{abstract}
Like a Letter, You is a collaborative investigation focused on the concept of 'conversation as an object'. Originally recorded as part of a larger self-produced project titled bEar Pixels, this track manifests as an experimental sound-based reconfiguration of an original essay about handwritten correspondence: How might an analog essay be performed as a digital assemblage of sound? In what ways are the methods of a DJ tied to speech, literature, and dialog? The track is composed using a cut-and-paste process of 'utterances', which may be described as units of speech distinct from language that may be oral or written and are inevitably completed by a response (Bakhtin 1986) which inevitably forms a dialog. Further, these speech units may manifest through gestures associated with digital tools as a form of cultural production (Noland 2009). Like a Letter, You includes a reading of the essay aloud, snippets of informal spoken conversations between the authors, and musical bits generated with a touch-based audio mixing platform. In effect, Like a Letter, You embodies the concepts of writing, dialog, and gesture within the genre of sound literature, and it also speaks to the unpredictable nature of collaboration and human interaction.
\end{abstract}

Resumo

Como uma carta, tu é uma investigação colaborativa focada no conceito de "conversa como objeto". Gravada originalmente como parte de um projeto autoproduzido mais amplo intitulado hEar Pixels, esta faixa constitui-se como uma reconfiguração experimental de base sonora de um ensaio original sobre correspondência manuscrita: de que forma pode um ensaio analógico ser levado a cabo como uma montagem digital de som? De que forma os métodos de um DJ se ligam ao discurso, à literatura e ao diálogo? A faixa é composta usando um processo de corte e colagem de "enunciados" que podem ser descritos como unidades de discurso distintas da linguagem, que podem ser orais ou escritos, e que se completam inevitavelmente por uma resposta (Bakhtin 1986), o que cria inevitavelmente um diálogo. Mais, estas unidades de discurso podem manifestar-se através de gestos associados a ferramentas digitais como uma forma de produção cultural (Noland 2009). Como uma carta, tu inclui uma leitura do ensaio em voz alta, pedaços de conversas orais informais entre os autores e pequenas partes [bits] musicais geradas com uma plataforma tátil de mistura áudio. Com efeito, 
Como uma carta, tu incorpora os conceitos de escrita, diálogo e gesto no âmbito do género da literatura sonora, e fala também sobre a natureza imprevisível da colaboração e da interação humana.

\section{References}

BAKHTIN, Mikhail (1986). Speech Genres and Other Late Essays. Austin: University of Texas Press.

NOLAND, Carrie (2009). Agency and Embodiment: Performing Gestures/Producing Culture. Cambridge, MA: Harvard University Press.

(C) 2017 Jessica Barness and Vince Giles. Licensed under the Creative Commons Attribution-NoncommercialNo Derivative Works 4.0 International (CC BY-NC-ND 4.0). 


\section{Télémaque}

\section{SANDRINe Deumier AND PhiLIPpe Lamy}

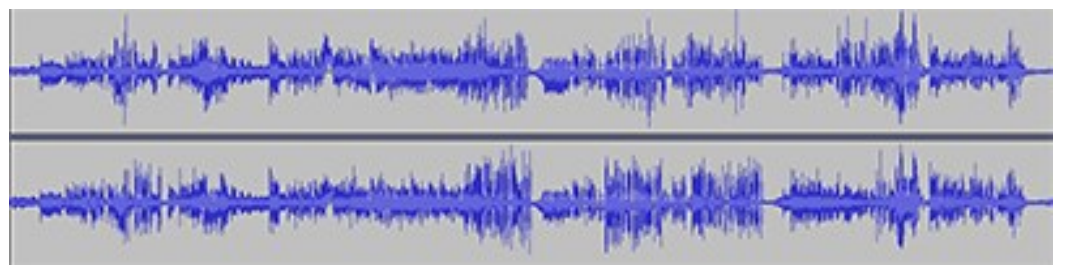

http://impactum-journals.uc.pt/matlit/article/view/5051/4218

\section{Résumé}

web fiction

"- [until the light takes us]

On track. Notifications (3). Dashboard. Prochaine destination - 4318'15.79" N

$5^{\circ} 23^{\prime} 07.04^{\prime \prime}$ E. Température ressentie: $23^{\circ}$. Prévision probabiliste sur très faible incertitude. Modifier votre profil. Voir votre profil public. Modifier vos préférences. @si proche. Courbure d'espace-temps ressentie: totale. Data recovery. Version d'essai gratuite.

Erreur. Cette boîte de dialogue a rencontré un paramètre incorrect. API Error Code: 100. Description: Invalid parameter. »

\footnotetext{
Abstract

web fiction

«- [until the light takes us]

On track. Notifications (3). Dashboard. Próximo destino - 43¹8'15.79” N

$5^{\circ} 23^{\prime} 07.04^{\prime \prime}$ E. Sensação térmica: $23^{\circ}$. Previsão probabilística sobre incerteza muito baixa. Modificar o seu perfil. Ver o seu perfil público. Modificar as suas preferências. @ tão perto. Sensação de curvatura do espaço-tempo: total. Data recovery. Versão de teste gratuita.

Erro. Esta caixa de diálogo encontrou um parâmetro incorreto. API Error Code: 100. Descrição: Invalid parameter.»
}

(C) 2017 Sandrine Deumier and Philippe Lamy. Licensed under the Creative Commons Attribution-NoncommercialNo Derivative Works 4.0 International (CC BY-NC-ND 4.0). 


\title{
Reading Thoreau in Another's Voice Reading Thoreau RYAN LALIBERTY
}

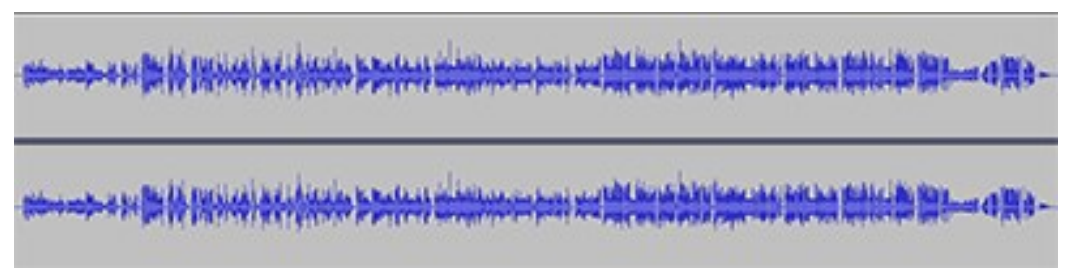

http://impactum-journals.uc.pt/matlit/article/view/5049/4222

\begin{abstract}
Reading Thoreau in Another's Voice Reading Thoreau is an experimental sound work that elucidates the complex network of materialities present in literature. Two sound sources are taken from two public-domain audio readings of Henry David Thoreau's Walden. The two verbatim excerpts - from the chapter "Sounds" where Thoreau expresses his at times ambivalence, at times exuberance, but constant alertness to the soundscape of Walden Pond — are fed into a modular synthesizer. Within the processing domain of the synthesizer, each excerpt is fed into an envelope detector that traces the volume contour of the reading, creating an extractable mimesis of the auditor's rhythm. These rhythmic envelopes are then applied to the opposite excerpt, forcing the reader to read in the rhythm of the other's voice. The resulting audio stutters and glitches as one reader opens and closes the mouth of the other. In concert, both readers open up pulsating oscillators that accompany the readings. Sound here is voltage, apart from all semantic content. As the rhythm of the reader's words is extracted, so too are the extra-semantic components that emerge from the noise of the recording. The network of $W$ alden is broadened thus to include the bodies of its auditors and the noises of its medium.
\end{abstract}

\section{Resumo}

Lendo Thoreau na Voz de Outro Lendo Thoreau é uma obra sonora experimental que lança luz sobre a complexa rede de materialidades presente na literatura. Duas fontes sonoras são retiradas de duas leituras de áudio em domínio público de $W$ alden, de Henry David Thoreau. Os dois trechos verbais - do capítulo "Sounds", no qual Thoreau expressa a sua ora ambivalência, ora exuberância, mas atenção constante em relação à paisagem sonora de Walden Pond — alimentam um sintetizador modular. Dentro do domínio de processamento do sintetizador, cada trecho alimenta um detetor de envolventes que traça o contorno do volume da leitura, criando uma mimese extraída do ritmo do ouvinte. Estes envolventes rítmicos são então aplicados ao trecho oposto, forçando o leitor a ler ao ritmo da voz do outro. O áudio que daí resulta gagueja e falha na medida em que cada leitor abre e fecha a boca do outro. Em concerto, ambos os leitores ativam osciladores que acompanham as leituras. $\mathrm{O}$ som aqui é a voltagem, 
para lá de todo o conteúdo semântico. À medida que o ritmo das palavras do leitor é extraído, também o são os componentes extra-semânticos que emergem do ruído da gravação. A rede de $W$ alden é assim ampliada para incluir os corpos dos seus ouvintes e os ruídos do meio.

(C) 2017 Ryan LaLiberty.

Licensed under the Creative Commons Attribution-NoncommercialNo Derivative Works 4.0 International (CC BY-NC-ND 4.0). 


\section{Umetnost Gubljenja \\ VLADIMIR VLADDA MILOYKOVITCH}

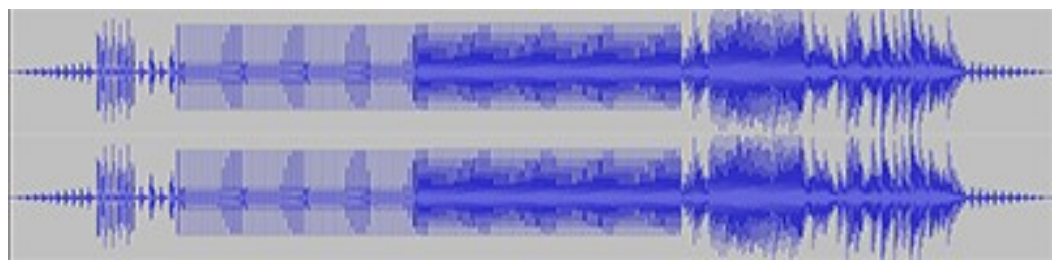

http://impactum-journals.uc.pt/matlit/article/view/5053/4214

\section{Abstract}

The audio poetry mix titled Umetnost Gubljenja [The Art of Losing/ Vanishing] uses cut-up technique in order to mix and adjust the text of the poem "Umetnost Gubljenja" to the audio poetry form. An unknown program was used for mixing in this totally homemade art work, authored by Vladimir Milojković (sometimes published under the name Vladimir Vladda Miloykovitch). The mix is 6 minutes and 35 seconds long, mono sound, mp3 format. Conceptually, it is, in a certain way, socially engaged poetry, questioning the role of art in the modern world. Effects influencing the listeners were achieved through repetition of crucial words and tone changing.

It is recommendable to listen the mix via headset for better experience.

\section{Resumo}

A mistura áudio poética intitulada Umetnost Gubljenja [A Arte do Desaparecimento] é uma técnica de mistura cut-up usada para ajustar o texto do poema "Umetnost Gubljenja” à forma poética áudio. Um programa desconhecido foi usado para a mistura, uma obra de arte totalmente caseira, da autoria de Vladimir Milojković (por vezes publicado com o nome Vladimir Vladda Miloykovitch). A mistura tem a duração de 6 minutos e 35 segundos, som mono, formato mp3. Conceptualmente é, de alguma forma, poesia socialmente comprometida, que questiona o papel da arte no mundo moderno. Os efeitos que influenciam os ouvintes foram obtidos através da repetição de palavras cruciais e de alteração de tons com vários efeitos sonoros. Recomenda-se a escuta com auscultadores para uma experiência melhor.

(C) 2017 Vladimir Vladda Miloykovitch.

Licensed under the Creative Commons Attribution-NoncommercialNo Derivative Works 4.0 International (CC BY-NC-ND 4.0). 


\section{Emma Soundscape \\ SARA PINHEIRO}

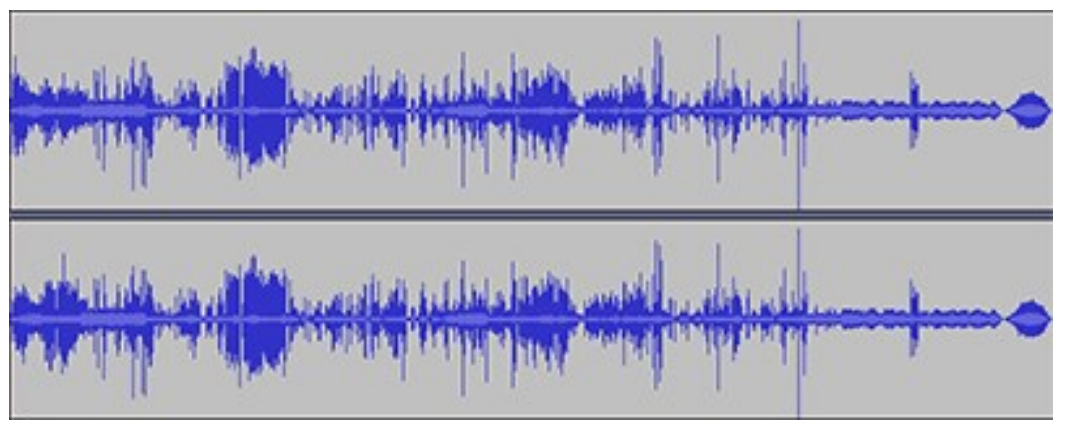

http://impactum-journals.uc.pt/matlit/article/view/5052/4167

\section{Resumo}

Esta peça é parte de uma instalação audiovisual de vários ecrãs, concebida pelas artistas visuais Mieke Bal e Michelle Williams-Gamaker. A instalação é baseada no romance de Flaubert Madame Bovary (1856). Emma (Madame B.) é uma ouvinte atenta e sensível ao ambiente que a rodeia. A banda sonora (quer na instalação, quer na longametragem) foi desenvolvida através de uma série de motivos sonoros que servem como caracterização sonora da personagem. Escutar estes motivos sonoros é um exercício de "focalização sonora": os objectos que a caracterizavam fa-lo-iam sonoramente também. A paisagem sonora de Emma reflecte os sons acumulados de uma vida individual, que simultaneamente forma e limita o espaço que a define. Estes sons marcam e traçam a história da personagem, eventualmente delineando 'a sua expansão no mundo tanto quanto a sua reclusão no mesmo'.

Deve ser ouvida preferencialmente com monitores, desde que não haja mais sons a interferir. A peça deverá ocupar uma sala vazia.

\section{Abstract}

This piece is part of a multi-screen audiovisual installation designed by visual artists Mieke Bal and Michelle Williams-Gamaker. The installation is based on Flaubert's novel Madame Bovary (1856). Emma (Madame B.) is an attentive and sensitive listener to the environment that surrounds her. The soundtrack (both in the installation and in the feature film) was developed through a series of sound-motifs that serve as sound characterization of the character. Listening to these sound-motifs is an exercise in "sonic focalization": the objects that characterized her would do so sonically as well. Emma's sound landscape reflects the accumulated sounds of an individual life, which simultaneously shape and confine the space that defines her. These sounds mark and trace the character's story, eventually outlining 'her expansion in the world as much as her seclusion in it'. 
It should be heard preferably with monitors, as long as there are no other interfering sounds. The piece should occupy an empty room.

C 2017 Sara Pinheiro.

Licensed under the Creative Commons Attribution-NoncommercialNo Derivative Works 4.0 International (CC BY-NC-ND 4.0). 


\section{Language Has No Positive Terms DAVID PRESCOTT-STEED}

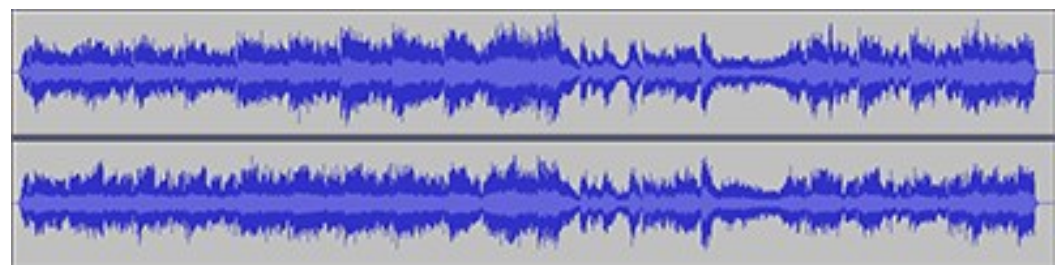

http://impactum-journals.uc.pt/matlit/article/view/5044/4227

\section{Abstract}

This sound art composition is a meditation on the arbitrariness of linguistic signs and the idea that language has no positive terms: "signs have no special right to mean something in particular and not something else" (Bignell: 9). As a first-time father, the interactions I have with my four-year-old daughter are mostly related to my responsibility to facilitate her sensory exploration of the world around her. This includes supporting her formalisation of linguistic expression and numeracy skills through story recall and construction, number identification, and pattern/rhythm awareness. These language-based learning activities benefit early childhood development by progressing a child's social awareness, confidence and resiliency. A tension exists, therefore, between the power of language as a vital navigational tool and the unassailable instability of meaning.

As a creative response, this composition features extracts from audio recordings of our conversations. The fragments of utterances, like the synthetic buzzing that returns and haunts, shift between audibility and inaudibility, meaning and nonmeaning. Each time it's played, digital audio technology brings our absence into the present; we become acousmatic textures inside the body of the listener "who cannot listen away as one can look away" (Connor: 133), oscillating the small bones in the middle ears and sending electrical signals to the brain. Through this treatment of language, we may be emptied of meaning but not of the positive meaningfulness of our interactions.

Resumo

Esta composição de arte sonora é uma reflexão sobre a arbitrariedade dos signos linguísticos e sobre a ideia de que a linguagem não tem termos positivos: "os signos não têm direito a significar algo em particular e não qualquer outra coisa" (Bignell: 9). Tendo sido pai pela primeira vez, a interação que tenho com a minha filha de 4 anos prende-se bastante com a minha responsabilidade em facilitar a exploração do mundo sensorial à sua volta. Isto inclui apoiar a sua formalização da expressão linguística e capacidade de cálculo através da construção e evocação de histórias, identificação de números, e consciência de padrões/ritmos. Estas atividades de aprendizagem basea- 
das na linguagem contribuem para o desenvolvimento da primeira infância ao estimular a consciência social da criança, e a sua confiança e resiliência. Assim, existe uma tensão entre o poder da linguagem como uma ferramenta vital de navegação e a instabilidade inexpugnável do sentido.

Enquanto resposta criativa, esta composição apresenta excertos de gravações áudio das nossa conversas. Os fragmentos dos nossos enunciados, como zumbido sintético que regressa e assombra, alternam entre a audibilidade e a inaudibilidade, o sentido e o não-sentido. De cada vez que é usada, a tecnologia áudio digital transporta a nossa ausência para o presente; transformamo-nos em texturas acusmáticas no interior do corpo do ouvinte que "não pode ouvir para o outro lado tal como se olha para o outro lado" (Connor: 133), oscilando os pequenos ossos no ouvido médio e enviando sinais elétricos para o cérebro. Através deste tratamento da linguagem, podemos ficar despojados do sentido mas não do significado positivo das nossas interações.

\section{References}

BIGNELL, Jonathan (2002). Media Semiotics: An Introduction. Manchester: Manchester University Press.

CONNOR, Steven (2011). "Ears Have Walls: On Hearing Art." Sound: Documents of Contemporary Art. Ed. Caleb Kelly. Cambridge, MA: The MIT Press. 129-39.

(C) 2017 David Prescott-Steed. Licensed under the Creative Commons Attribution-NoncommercialNo Derivative Works 4.0 International (CC BY-NC-ND 4.0). 